九州大学学術情報リポジトリ

Kyushu University Institutional Repository

\title{
Clay Mineralogy of Paddy Soils in Thailand and Malaysia
}

Wada, Koj i

Laboratory of Soils, Faculty of Agriculture, Kyushu University

Kakuto, Yasuko

Laboratory of Soils, Faculty of Agriculture, Kyushu University

Yamada, Yoshio

Laboratory of Soil Fertility and Plant Nutrition, Faculty of Agriculture, Kyushu University

Vacharotayan, Sorasith

Faculty of Agriculture, Kasetsart University

https://doi.org/10.5109/23731

出版情報: 九州大学大学院農学研究院紀要. 25 (4)，pp.223-239，1981-04. Kyushu University バージョン：

権利関係 : 


\title{
Clay Mineralogy of Paddy Soils in Thailand and M alaysia
}

\author{
Koji Wada*, Yasuko Kakuto* and Yoshio Yamada** \\ Faculty of Agriculture, Kyushu University 46-02, Fukuoka 812
}

Sorasith Vacharotayan

Faculty of Agriculture, Kasetsart University, Bangkok, Thailand

(Received January 29, 1981)

\begin{abstract}
The clay mineralogy of paddy soils collected from 28 sites in Thailand and Malaysia that represent 19 soil series was studied by X-ray diffraction analysis. Most soils contain kaolinite, 2 : 1 mixed-layer minerals and mica. Chlorite and chloritesmectite or vermiculite intergrades are rather rare species. The mixed-layer minerals consist of random stratification of smectite/vermiculite/mica or smectite/ mica that differ in their major mineral species. All the $2: 1$ layer silicates are dioctahedral and most smectite is a high-charge type. The contents of the minerals in the clay show regional and physiographic variations. No or little hydroxyAl interlayering was related to a weak "grayzation" (gray coloring) of the paddy soils. The potential productivity of the soils was estimated on the basis of the contents of mica and 2:1 mixed layer minerals that increase from soils derived from old to recent alluvium and further to those derived from marine and brackish water deposits.
\end{abstract}

\section{INTRODUCTION}

As a part of International Cooperative Studies on the Increasing Productivity of Soils in Tropical Area (1976-1978), clay mineralogy of paddy soils in Thailand and Malaysia was studied. Research in soil mineralogy has led to findings which are of great significance to soil chemistry, soil genesis and soil fertility. Application of these findings can, however, be made only to soil systems with considerable qualification. Clay mineral composition of paddy soils in Malaysia and/or Thailand has been studied by several investigators (Vacharotayan et al., 1962; Hattori et al., 1965 ; Kawaguchi and Kyuma, 1969a, b; Motomura, 1973; Breemen, 1976). The first purpose of the present study is to provide information about clay minerals in paddy soils on which the effects on crop yield of nitrogen and other fertilizers has been measured. The second is to discuss genetic implications of their clay mineralogy and to estimate the potential productivity of these soils on the basis of their clay content and clay mineral composition.

* Laboratory of Soils.

** Laboratory of Soil Fertility and Plant Nutrition. 


\section{FIELD STUDIES AND SAMPLING}

Field studies were carried out in December of 1977 and December of 1978 in Thailand and Malaysia. Partial descriptions of paddy soils studied are given in Table 1. They were located in experimental plots of 1 university, 10 rice experiment stations and 1 rice research institute and in 15 farmer's fields in the main rice-growing area of Thailand and Malaysia (Appendixes 1 and 2). The following morphological characteristics together with locations were recorded for each soil profile whenever possible; 1) thickness of horizons, 2) color, 3) mottles and concretions, 4) compactness, and 5) texture (Appendix 1). When soil profile was unable to be observed under waterlogged condition or due to other reasons, only a soil sample of Ap horizon was taken and its location

Table 1. Soil samples.

\begin{tabular}{|c|c|c|c|c|c|}
\hline \multicolumn{2}{|r|}{ Region } & $\begin{array}{l}\text { Soil } \\
\text { series }\end{array}$ & $\begin{array}{l}\text { Site } \\
\text { No. }\end{array}$ & $\begin{array}{l}\text { Parent } \\
\text { material }\end{array}$ & Physiography \\
\hline & \multirow{3}{*}{$\begin{array}{l}\text { Northern } \\
\text { Valleys }\end{array}$} & \multirow[t]{2}{*}{ Sansai } & TL-1 & Old alluvium & \multirow{2}{*}{$\begin{array}{l}\text { Old alluvial } \\
\text { terraces and fans } \\
\text { " }\end{array}$} \\
\hline & & & $\begin{array}{l}\text { TL-2 } \\
\text { TL-4 } \\
\text { TL-3 }\end{array}$ & $\begin{array}{c}\text { " } \\
\text { Recent alluvium }\end{array}$ & \\
\hline & & $\begin{array}{l}\text { Hangdong- } \\
\text { Phimai } \\
\text { Phimai }\end{array}$ & $\begin{array}{l}\text { TL-5 } \\
\text { TL-6 }\end{array}$ & Recent „alluvium & Flood plains \\
\hline \multirow[t]{2}{*}{ II } & \multirow[t]{2}{*}{ Khon Kaen } & Roi Et & TL-8 & Semi-recent & Low terraces \\
\hline & & Ratchaburi & $\begin{array}{l}\text { TL-9 } \\
\text { TL-7 }\end{array}$ & $\begin{array}{l}\text { alluvium } \\
\text { Recent alluvium }\end{array}$ & Flood "plains \\
\hline \multirow[t]{7}{*}{ III } & \multirow{7}{*}{$\begin{array}{l}\text { Bangkok } \\
\text { Plain }\end{array}$} & Klaeng & TL-25 & Old alluvium & Low terraces \\
\hline & & $\begin{array}{l}\text { Lop Buri } \\
\text { Saraburi } \\
\text { Ongkharak }\end{array}$ & $\begin{array}{l}\text { TL-27 } \\
\text { TL-12 } \\
\text { TL-29 }\end{array}$ & \multirow{2}{*}{$\begin{array}{l}\text { Marine" and brackish } \\
\text { water deposits (acid) }\end{array}$} & Former tidal flats \\
\hline & & Thanyaburi & TL-10 & & " \\
\hline & & Rangsit & TL-11 & " & " \\
\hline & & Ayut & TL-21 & & " \\
\hline & & \multirow[t]{2}{*}{ Bangkok } & TL-23 & \multirow{2}{*}{$\begin{array}{l}\text { Marine and brackish } \\
\text { water deposits (non-acid) }\end{array}$} & " \\
\hline & & & TL-24 & & ) \\
\hline \multirow{3}{*}{\multicolumn{2}{|c|}{$\begin{array}{l}\text { IV Peninsula } \\
\text { a. South East } \\
\text { Coast } \\
\text { (Thailand) }\end{array}$}} & & & & \\
\hline & & Klaeng & $\begin{array}{l}\text { TL-31 } \\
\text { TL-32 }\end{array}$ & $\begin{array}{l}\text { Old alluvium } \\
\text { " }\end{array}$ & $\begin{array}{c}\text { Low terraces } \\
\text { " }\end{array}$ \\
\hline & & $\begin{array}{l}\text { Samut } \\
\text { Prakan }\end{array}$ & TL30 & $\begin{array}{l}\text { Marine and brackish } \\
\text { water deuosits (non- }\end{array}$ & Former tidal flats \\
\hline \multirow[t]{5}{*}{ b. } & \multirow{5}{*}{$\begin{array}{l}\text { Middle } \\
\text { West } \\
\text { Coast } \\
\text { (Malaysia) }\end{array}$} & Hutan & ML-13 & Recent alluvium & Flood plains \\
\hline & & $\begin{array}{l}\text { Tualang- } \\
\text { Kundor }\end{array}$ & ML-11 & $\begin{array}{l}\text { Recent alluvium- } \\
\text { Marine and brackish }\end{array}$ & $\begin{array}{l}\text { Flood plains- } \\
\text { Former tidal flats }\end{array}$ \\
\hline & & & ML-12 & \multirow{3}{*}{$\begin{array}{l}\text { Marine" and brackish } \\
\text { water deposits (acid) } \\
\text { " }\end{array}$} & \multirow{3}{*}{ Former tidal flats } \\
\hline & & Kundor & ML & & \\
\hline & & Guar & ML-15 & & \\
\hline
\end{tabular}


was recorded (Appendix 2). Soil series names and great soil groups in Appendix 1 were identified by referring to the Detailed Reconnaissance Soil Maps of Thailand which had been published by the Department of Land Development, Ministry of Agriculture and Cooperative, Kingdom of Thailand.

\section{LABORATORY STUDIES}

\section{Particle-size distribution analysis}

Ten grams of air-dry soil sample were treated with $6 \% \mathrm{H}_{2} \mathrm{O}_{2}$ and washed with water by centrifugation. The treated soil was dispersed at $\mathrm{pH} 10(\mathrm{NaOH})$ by shaking on a reciprocating shaker. The clay, silt and sand were collected by repeated dispersion and sedimentation or by sieving, and their weights were determined. Texture was designated according to the International System of Textural Classification.

\section{Clay mineral analysis}

The clays collected for the particle-size distribution analysis were kept as flocculated suspensions by adding small amounts of $\mathrm{NaCl}$. The clay was treated with dithionite-citrate and then saturated with $\mathrm{Mg}^{2+}$ and $\mathrm{K}+$. The $\mathrm{X}$-ray analysis was carried out using samples oriented on glass slides; air-dried and solvated with glycerol for a Mg-saturated sample and air-dried and heated at $300^{\circ} \mathrm{C}$ and $550^{\circ} \mathrm{C}$ for a K-saturated sample (Wada, 1966). The presence of kaolinite was also detected using a hydrazine intercalation procedure (Wada and Yamada, 1968). For selected samples, the clay fractions $(<2 \mu \mathrm{m} ; 0.2-2.0 \mu \mathrm{m}$ and $<0.2 \mu \mathrm{m}$ ) were separated, and the X-ray analysis was carried out using samples prepared without the treatment with dithionite-citrate.

\section{EXPERIMENTAL RESULTS}

\section{Particle-size distribution analysis}

The results of particle-size distribution analysis are given in Table 2 in which soil samples are classified into 4 groups according to their geographical distribution and physiography.

Generally, the variation of texture between horizons in a profile is small. Soils in Region I (Northern Valleys) show two contrasting textures (Table 2). The Sansai series is characterized by the low content of clay and the high content of fine sand, while the Phimai series by the high content of clay and silt. This difference in texture is correlated with the levels of terraces and flood plains on which these soils are located, as observed by Kawaguchi and Kyuma (1969a). Soils on the lower or younger flood plains are definitely heavier in texture than those on the higher or older terraces. Similar differences and correlations are also found between the Roi Et and Ratchaburi series in Region II (around Khon Kaen), the Klaeng and Sara Buri series and other soil series in Region III (Central Plain) and the Klaeng and Samut Prakan series in Region IVa (South East Coast of Peninsula), but not for soils in Region IVb (Middle West Coast of Peninsula). 
Table 2. Particle-size distribution of soil samples.

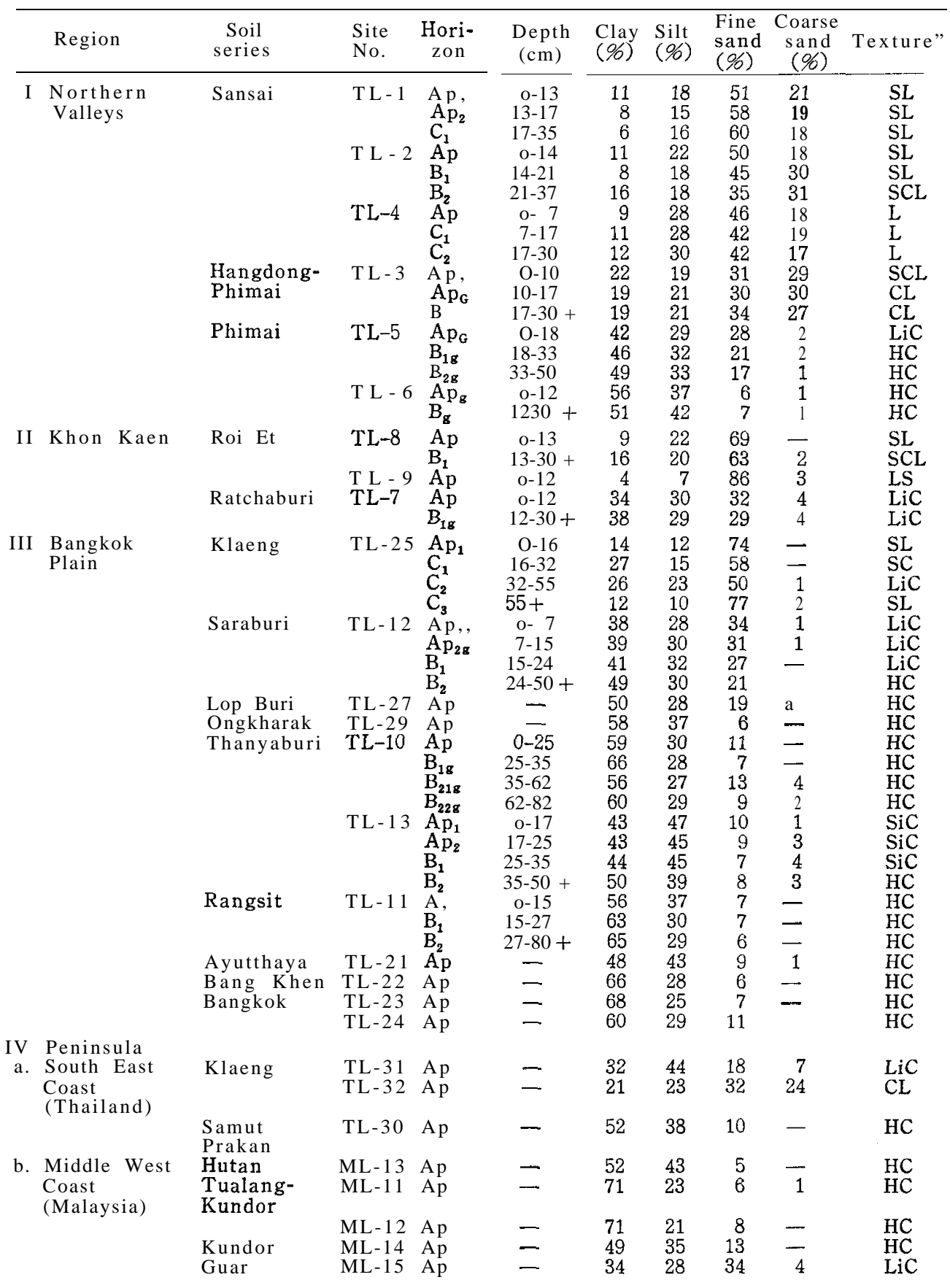

1) CL, clay loam; HC, heavy clay; L. loam; LiC, light clay; LS, loamy sand; SCL. sandy clay loam; SL, sandy loam. 
The Roi Et series in Region III is characterized by the very high content of fine sand (Table 2). This feature is probably correlated with the uniqueness in parent material being composed exclusively of weathered Mesozoic sandstones. Some soils derived from marine and brackish water deposits on former tidal flats in Regions III and IV are very heavy and their clay content exceeds $60 \%$. No particular difference in texture is found between soils derived from acid and non-acid marine-brackish water deposits in these regions.

\section{Clay mineral analysis}

Clay mineral composition of paddy soils in Thailand and Malaysia is fairly simple (Table 3). Clay fractions of most soils consist of kaolinite, $2: 1$ mixed layer minerals and mica. The $2: 1$ mixed layer minerals consist of vermiculite and/or smectite with mica. Only several soils contain smectite and/or vermiculite as discrete mineral species, and two soils chlorite. Kawaguchi and Kyuma (1969a) also reported that the paddy soils of Thailand do not generally contain chlorite, except for a few soils in the Northern Valley.

$1: 1$ layer silicates in all samples gave a well-defined (001) peak at 7.15$7.2 \AA$ but no $(020,110)$ peak at $4.45 \AA$ when oriented on glass slides. On this basis, they were identified as kaolinite. Kaolinite was present both in the fine $(<0.2 \mu \mathrm{m})$ and coarse $(0.2-2 \mu \mathrm{m})$ clay fractions. Its relative contents in the two size-fractions varied considerably.

Mica was present both in the fine and coarse clay fractions as a constituent of 2: 1 mixed layer silicates, and mostly in the coarse clay fraction as a discrete mineral species. Its $(060)$ peak at $1.50 \AA$ indicated that it is dioctahedral and contains $\mathrm{Al}^{3+}$ as octahedral cations.

A marked rise of X-ray scattering near to the primary beam indicated the random mixed-layering of $2: 1$ layer minerals. Four types of $2: 1$ mixedlayer mineral species were distinguished. Their diagnostic X-ray diffraction features, type specimens and probable compositions are given in Fig. 1. Species $\mathrm{A}, \mathrm{B}$ and $\mathrm{C}$ are considered to consist of random mixed-layering of smectite/vermiculite/mica and to contain mica, vermiculite or smectite as a dominant mineral species respectively, while species $\mathrm{D}$ is considered a smectite-rich smectite/mica mixed layer mineral. These four species of the mixed-layer minerals intergrade and are often difficult to differentiate from each other (Table 3).

The presence of the $2: 1$ mixed layer minerals in Thai and Malaysian paddy soils does not seem to have received due attention despite of their ubiquitous occurrence (Table 3). Their composition and association suggest that smectite and vermiculite are derived from mica. This suggestion is supported by that the (060) spacing of all the $2: 1$ layer silicates in the mixed-layer minerals is about $1.50 \AA$ and that most or a considerable portion of smectite is a high-charge type which collapses more easily to $10 \AA$ by K-saturation than does a low-charge type. The finding would have an important implication on the retention of $\mathrm{K}+$ and $\mathrm{NH},+$ in the soil, because high-charge smectite as well as vermiculite exhibits strong preference for these cations.

Chlorite-smectite or chlorite-vermiculite intergrades were not found in all 
Table 3. Approximate clay mineral contents of soil samples (\%).

\begin{tabular}{|c|c|c|c|c|c|c|c|c|c|c|c|c|}
\hline & & & & & i - & & & Clay & inera & & & \\
\hline & Region & series & No. & zon & $\mathrm{K} \mathrm{t}$ & M & $\begin{array}{r}2 \\
\text { M. L. }\end{array}$ & $\begin{array}{l}1 \\
\text { M.2' } \\
\end{array}$ & $\mathrm{Sm}$ & $V t$ & $\mathrm{Ch}$ & $\mathrm{Vt}-\mathrm{Ch}$ \\
\hline I & Northern & Sansai & TL-1 & Ap, & 77 & 8 & 14 & A & - & - & - & - \\
\hline & Valleys & & & $\mathrm{Ap}_{2}$ & 76 & 10 & 14 & A & & $\cdots$ & $\rightarrow$ & - \\
\hline & & & & & 81 & 9 & & A & 一 & & & \\
\hline & & & TL-2 & Ap & 67 & 13 & 20 & $\mathrm{c}$ & - & $m$ & $-\cdot$ & - \\
\hline & & & & $\mathrm{B}_{1}$ & 7469 & $\begin{array}{l}17 \\
14\end{array}$ & $\begin{array}{l}10 \\
17\end{array}$ & $\begin{array}{l}A-C \\
A-C\end{array}$ & - & & - & $\rightarrow$ \\
\hline & & & 'TL-4 & $\mathrm{Ap}_{\mathrm{p}}^{2}$ & 61 & 17 & 22 & $\mathrm{c}$ & & & - & - \\
\hline & & & & $\mathrm{C}_{1}$ & 60 & 20 & 20 & A-C & & & & \\
\hline & & & & $\mathrm{C}_{2}$ & 57 & 18 & 25 & A-C & & & & \\
\hline & & Hangdong- & TL-3 & $A p_{1}$ & 55 & 7 & 38 & B - D & - & & & - \\
\hline & & Phimai & & $\begin{array}{l}\mathrm{Ap}_{\mathrm{G}} \\
.\end{array}$ & $\begin{array}{r}60 \\
63\end{array}$ & $\begin{array}{l}11 \\
19\end{array}$ & $\begin{array}{l}29 \\
18\end{array}$ & $\begin{array}{l}B-D \\
B-D\end{array}$ & 一 & - & & - \\
\hline & & Phimai & TL-5 & Ap, & 55 & 13 & 33 & B - D & - & & & \\
\hline & & & & $\mathrm{B}_{1 \mathrm{~g}}$ & 57 & 18 & 25 & A-C & - & & - & - \\
\hline & & & & $\mathrm{B}_{2 g}$ & 55 & 16 & 29 & B - C & - & - & $\cdots$ & - \\
\hline & & & TL -6 & $\mathrm{Ap}_{\mathrm{g}}$ & $\begin{array}{l}53 \\
46\end{array}$ & $\begin{array}{l}18 \\
20\end{array}$ & - & - & $\begin{array}{r}5 \\
14\end{array}$ & $\begin{array}{l}20 \\
12\end{array}$ & $\begin{array}{l}4 \\
7\end{array}$ & \\
\hline II & Khon Kaen & Roi Et & $\mathrm{T} \mathrm{L}-8$ & $\mathrm{Ap}$ & 42 & 21 & 37 & B & - & - - & & - \\
\hline & & & & $\mathrm{B}_{1}$ & 34 & 14 & 52 & B & 一 & & & \\
\hline & & & TL-9 & $A p$ & 60 & 8 & 32 & $\mathrm{D}$ & - & & - & - \\
\hline & & Ratchaburi & TL -7 & $\mathrm{Ap}$ & 36 & 22 & 42 & B & 一 & & & \\
\hline & & & & B. ${ }_{18}$ & 28 & 11 & 61 & B & - & - & - & - \\
\hline III & Bangkok & Klaeng & $\mathrm{T} L-25$ & $5 \quad \mathrm{Ap}_{1}$ & 60 & 13 & 27 & D & - & & - & - \\
\hline & Plain & & & $\sim C$ & 57 & 19 & 24 & D & 一 & 一 & & 一 \\
\hline & & Lop Buri & TL-27 & $\mathrm{Ap}_{2}$ & $\begin{array}{l}30 \\
36\end{array}$ & 18 & 28 & D & $\overline{64}$ & - & 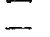 & - \\
\hline & & Saraburi & TL- 12 & $\mathrm{Ap}_{1 \mathrm{~g}}$ & 39 & 16 & 43 & B - D & - & - & 2 & \\
\hline & & & & $\mathrm{Ap}_{2 \mathrm{~g}}$ & 45 & 16 & 38 & B - D & - & & - & $\ldots$ \\
\hline & & & & $\mathrm{B}_{1}$ & 52 & 22 & 26 & B - D & 一 & & & - \\
\hline & & & & $\mathrm{B}_{2}^{2}$ & 50 & 17 & 33 & B - D & - & & & - \\
\hline & & Ongkharak & TL-29 & $A p$ & 61 & 14 & 25 & B - D & & & & \\
\hline & & Thanyaburi & TL-10 & $\mathrm{Ap}$ & 46 & 13 & 41 & B - D & - & & & \\
\hline & & & & $\mathrm{B}_{18}$ & $\begin{array}{l}58 \\
56\end{array}$ & $\begin{array}{l}17 \\
18\end{array}$ & $\begin{array}{l}25 \\
26\end{array}$ & $\begin{array}{l}\text { B-D } \\
\text { B-D }\end{array}$ & & & & \\
\hline & & & & $B_{228}^{218}$ & 50 & 24 & 26 & $\mathrm{~B}-\mathrm{D}$ & - & & 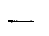 & - \\
\hline & & & TL- 13 & $\mathrm{Ap}_{1}$ & 48 & 12 & 39 & B - D & 一 & - & - & - \\
\hline & & & & $\mathrm{Ap}_{2}$ & 60 & 20 & 20 & B - D & - & & - & - \\
\hline & & & & $\mathrm{B}_{1}$ & 50 & 15 & 34 & B - D & 一 & & & \\
\hline & & Rangsit & TL- 11 & $\mathrm{~B}_{2}$ & $\begin{array}{l}51 \\
52\end{array}$ & $\begin{array}{l}17 \\
13\end{array}$ & $\begin{array}{l}32 \\
35\end{array}$ & $\begin{array}{l}\text { B - D } \\
\text { D }\end{array}$ & 一 & & & \\
\hline & & & "I & $\mathrm{B}_{1}$ & 58 & 16 & 26 & $\mathrm{D}$ & & & & \\
\hline & & & & $\mathrm{B}_{2}$ & 60 & 16 & 24 & $\mathrm{D}$ & & & & \\
\hline & & Ayutthaya & TL-21 & Ap & 54 & 25 & 21 & $\mathrm{D}$ & & & & \\
\hline & & Bang Khen & TL-22 & Ap & 52 & 27 & 21 & $C-D$ & $\longrightarrow$ & & & \\
\hline & & Bangkok & TL-23 & Ap & 56 & 25 & 19 & C-D & & & & \\
\hline & & & TL-24 & Ap & 59 & 20 & 22 & C-D & $\longrightarrow$ & & & - \\
\hline IV & Peninsula & & & & & & & & & & & \\
\hline a. & South East & Klaeng & TL-3 1 & Ap & 90 & 2 & & & $一$ & 2 & - & 5 \\
\hline & $\begin{array}{l}\text { Coast } \\
\text { (Thailand) }\end{array}$ & & $1 L-32$ & Ap & 91 & 4 & - & & $\rightarrow$ & 0 & & - \\
\hline & & Samut & TL-30 & Ap & 70 & 10 & 20 & $\mathrm{D}$ & 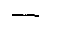 & & & \\
\hline b. & Middle West & $\begin{array}{l}\text { Prakan } \\
\text { Hutan }\end{array}$ & & An & 69 & 16 & 14 & B-D & & & & 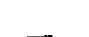 \\
\hline & Coast & Tualang. & ML- 11 & Ap & 88 & 5 & 7 & $\mathrm{~B}$ & & & & - \\
\hline & & & ML-12 & $A p$ & 83 & 7 & 10 & D & & & & $\cdots$ \\
\hline & & Kundor & ML-14 & Ap & 65 & 18 & 18 & $\mathrm{D}$ & $\rightarrow$ & & & - \\
\hline & & Guar & ML-15 & Ap & 68 & 13 & - & - & 19 & & & - \\
\hline
\end{tabular}

1) Abbreviation: Kt, kaolinite ; M, mica; M. L. M., 2 : 1 mixed-layer minerals; Sm. smectite ; Vt, vermiculite ; Ch, chlorite ; Vt-Ch, vermiculite-chlorite intergrades.

2) Abbreviation: A, Sm/Vt/M (M-rich phase); B; Sm/Vt/M (Vt-rich phase); C, Sm/ $\mathrm{Vt} / \mathrm{M}$ (Sm-Vt rich phase); D, Sm/M (Sm-rich phase). See Fig. 1 for example. 

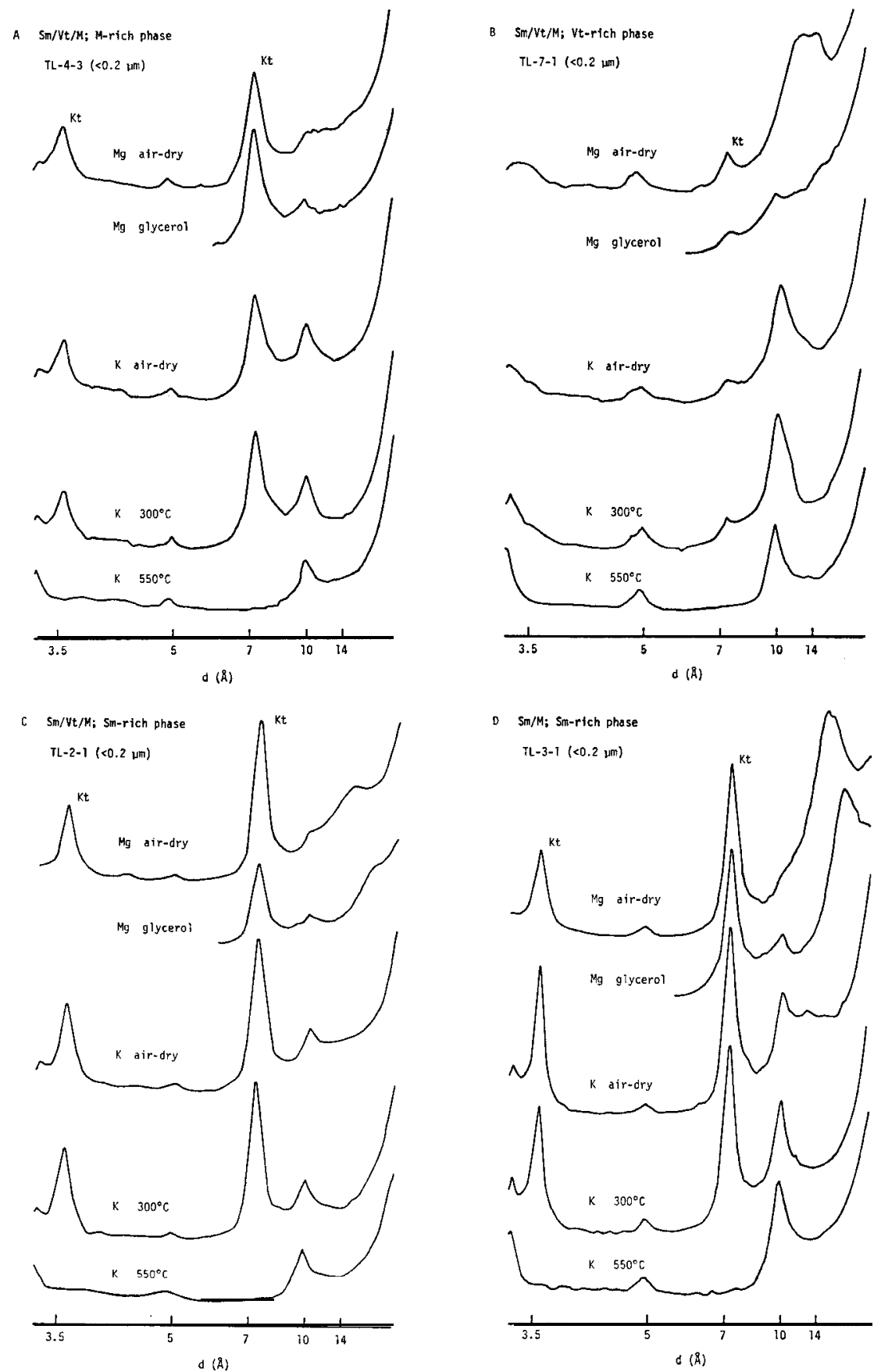

Fig. 1. X-ray diffraction features of $2: 1$ mixed-layer minerals in type specimens. A, B, C and D denote mineral species consisting of random interstratification of $\mathrm{M}$ (mica), Sm (smectite) and Vt (vermiculite). Kt denotes the peaks due to kaolinite. 
the clays treated with dithionite-citrate, except for soils TL-31 (Klaeng) and ML-14 (Kundor). The adopted criterion is the response to heat treatment of $\mathrm{K}$-saturated sample that has been known most useful in recognizing the hydroxy-Al inter-layering (Barnhisel, 1977). Either smectite or vermiculite present showed a complete collapse to $10 \AA$ by K-saturation and heating at $300^{\circ} \mathrm{C}$. The result indicates that at least strong hydroxy-Al inter-layering or chloritization of smectite or vermiculite does not occur in the paddy soils examined. Furthermore, several soils (TL-2-1 and TL-4-3, Sansai; TL-3-1, HangdongPhimai; TL-8-2, Roi Et) which show illuviation of iron and manganese (Table 2) and two acid sulfate soils (TL-10, Thanyaburi; TL-11, Rangsit) were selected, and their clay fractions were reexamined for the hydroxy-Al interlayering without dithionite-citrate treatment. The results indicated no or little, if any, hydroxy-Al inter-layering in these samples too.

The presence of chloritized $2: 1$ layer minerals in paddy soils of Thailand and Malaysia was reported by Hattori et al. (1965) and Kawaguchi and Kyuma $(1969 \mathrm{a}, \mathrm{b})$, and that in surface horizons of acid sulfate soils in the Bangkok Plain by Breemen (1976). Hattori et al. (1965) used the appearance of the (001) diffraction at 19-20 A or 14-15 $\mathrm{A}$ for the Mg-saturated and glycerol solvated sample and at 14-15 $\AA$ for the K-saturated and air-dried sample as criteria for distinguishing hydroxy-Al interlayered smectite or vermiculite. Kawaguchi and Kyuma (1969a, b) did not state the criteria they used. Breemen (1976) used two criteria; the absence of any eminent peak for the Mg-saturated and glycerol solvated sample and the tailing of the $10 \AA$ peak to higher spacings for the K-saturated and air-dried sample. These two features, however, can be seen in Fig. 1 for the respective samples of the mixed-layer mineral species $\mathrm{B}$ and $\mathrm{D}$.

Relative contents of layer silicates in Table 3 were estimated simply by reading the (001) peak heights at $7 \AA$ for kaolinite, at $10 \AA$ for $2: 1$ layer silicates and at $14 \AA$ for chlorite and vermiculite-chlorite intergrade and by assuming the same proportionality between the (001) peak height and the content of each mineral. All the (001) peak heights for the Mg- and K-saturated samples of each soil clay were normalized against the (001) peak height of kaolinite for the Mg-saturated and air-dried sample, considering the facts that kaolinite is least affected by saturation with different cations, solvation with glycerol and heating, and that chlorite and chlorite-vermiculite intergrade are absent in most samples. The content of mixed-layer mineral species was estimated on the basis of the difference in the normalized peak height at 10 $\AA$ between the Mg-saturated and air-dried sample and the K-saturated and $550^{\circ} \mathrm{C}$ heated sample. The estimates thus obtained are of very approximate nature but can be used to compare the clay mineral composition between the soils such as those in the present study, in which the constituent minerals are limited in number, and the nature of each mineral is not much different. The difference in the clay mineral composition between the horizons of each soil was generally small, indicating that alluvial deposits from which the soil had been developed consist of fairly homogeneous materials.

Kaolinite content is very high (70-90\%) in soils located on the Peninsula 
followed by two soils in the Northern Valleys, the Sansai and Hangdong-Phimai series (Table 3). Solis in the Bangkok Plain and two Phimai soils in the Northern Valleys had medium contents of kaolinite (40-60 \%). Two Roi Et and one Ratchaburi soils around Khon Kaen have lowest contents of kaolinite $(<40 \%)$. The observed regional difference in the content of kaolinite was generally similar to that reported by Kawaguchi and Kyuma (1969a). Normative kaolinite contents were reported about $60 \%$ in acid sulfate soils of Peninsula Thailand, between 40and $55 \%$ in acid sulfate soils and between 25 and $40 \%$ in non-acid to para-acid sulfate soils in the Bangkok Plain (Breemen, 1976).

The content of mica shows relatively small variations and is in the range from 10 to $20 \%$ in most soils (Table 3). Soils of the Ayuthaya, Bang Khen and Bangkok series derived from very recent, marine and brackish water deposits had higher contents of mica $(20-25 \%)$, while those of the Klaeng and Kundor-Tualang series in the South and of the Sansai series in the North had lower contents of mica. The content of illite based on its $\mathrm{K}_{2} \mathrm{O}$ content of $7.0 \%$ was estimated in the range 30-35 $\%$ in the soils in the Bangkok Plain (Breemen, 1976). The difference between 20-25\% and 30-35\% suggests that the X-ray diffraction procedure used in the present study underestimates the content of mica to some extent, but the latter $30-35 \%$ includes mica as a constituent of $2: 1$ mixed layer minerals.

The occurrence of the four species of the mixed-layer minerals in soils shows correlations with their geographical and physiographical settings (Table 3). In many soils, the species of the mixed-layer minerals do not change with depth, but there are some exceptions, possibly reflecting the change in the nature of deposits with time. Soils of the Sansai series on the old alluvial terraces and fans in the Northern Valleys are characterized by the presence of species $\mathrm{A}$ and $\mathrm{C}$ that are considered mica-rich and smectite-rich phases of the mixed-layer minerals respectively (Fig. 1) and by their low content (Table 3). On the other hand, nearly all soils derived from more recent to very recent alluvium on the low terraces and former tidal flats in the Bangkok Plain contain smectite-rich species D together with species B or C. The content of the mixed-layer minerals in these soils ranges from about 20 to $40 \%$. In the South (Region IV), most of soils contain also species B and/or D, but their content is lower than $20 \%$. One Roi Et and one Ratchaburi soil around Khon Kaen are characterized by the high content of vermiculite-rich species B. Two soils of the Phimai series located in the different valleys in the Northern Valleys both contain smectite and vermiculite, but differ in their occurrence. They are present as distinct mineral species in one soil but as mixed-layer minerals in the other, probably reflecting the difference in the nature of the parent rocks in the catchment area.

\section{DISCUSSION}

The examined paddy soils in Thailand and Malaysia show no such divergence in their clay mineral composition as found with paddy soils in Japan 
(Hattori, 1978). Most of sediments from which those paddy soils are derived consist of materials which are well-weathered and disintegrated under tropical conditions. Sorting of weathered material in transportation by river followed by subsequent alteration after deposition accounts for the regional and physiographic differences in clay mineral composition (Table 3).

No or little hydroxy-Al interlayering in smectite and vermiculite occurs in the examined paddy soils in Thailand and Malaysia. The hydroxy-Al interlayering or chloritization associated with "grayzation" (gray coloring) (Mitsuchi, 1974b), particularly in Ap horizons, has been reported to occur fairly extensively in paddy soils in Japan (Mitsuchi, 1974a; Inoue et al., 1977; Hattori, 1978). The hydroxy-Al interlayering has also been reported in paddy soils in Thailand and Malaysia (Hattori et al., 1965; Kawaguchi and Kyuma, 1969a, b). Hattori et al. (1965) stated that it is not as conspicuous as in Japanese paddy soils, but proceeds in most surface soils. No or little hydroxy-Al interlayering in paddy soils in the tropical area may be related with the general weakness of "grayzation" in these soils, as appeared in soil color (Table 2).

Breemen (1976) suggested on the basis of his X-ray diffraction and other studies that the hydroxy-Al interlayering is an important process in the periodically reduced surface horizons of acid sulfate soils. The finding in the present study indicated the weakness in his X-ray verification of the hydroxy-Al interlayering. Besides this, the strong acidity that developes in acid sulfate soils would favor the formation of $\mathrm{Al}\left(\mathrm{H}_{2} \mathrm{O}\right)_{6}{ }^{3+}$ on the one hand, and inhibit the hydrolysis of $\mathrm{Al}\left(\mathrm{H}_{2} \mathrm{O}\right)_{6}{ }^{3+}$ on the other, even under waterlogged conditions. There are studies that differ in their finding on the balance of these reactions; disappearance of soluble and exchangeable aluminum from acid sulfate soils by flooding was found by Park et al. (1971) and Sombatpanit and Wangpaiboon (1973) (quoted by Breemen, 1976), whereas little change of soluble aluminum was found by Huynh-tong-Tho and Egashira (1976).

The hydroxy-Al interlayering has implications not only to soil genesis but to soil productivity, because it affects the cation exchange of vermiculite and smectite present in the soil. No or little hydroxy-Al interlayering in paddy soils would generally favor the retention of cations, particularly $\mathrm{K}+$ and $\mathrm{NH}_{4}{ }^{+}$ in these soils. Studies on their charge characteristics throw light on the effect of the hydroxy-Al interlayering in paddy soils in tropical area.

Kaolinite is chemically inert, though its finer particles can exhibit cationexchange capacity up to $10 \mathrm{me} / 100 \mathrm{~g}$. Micas are important as a source of potassium to plant, though the release of potassium, particularly from their coarse-clay size particles, is rather slow. The extensive occurrence of mica in paddy soils in Thailand and Malaysia should favor the status of available potassium in these soils. The nature and content of mixed-layer minerals consisting of mica, vermiculite and/ or smectite are important, because they affect soil fertility through cation exchange and retention of $\mathrm{K}+$ and $\mathrm{NH},+$. Species $A$ and $B$ would strongly retain $\mathrm{K}+$ and $\mathrm{NH}_{4}{ }^{+}$, while species $\mathrm{B}, \mathrm{C}$ and $\mathrm{D}$ act as an effective cation exchanger.

Tables 4 and 5 show classification of surface soils on the basis of the contents of mica and 2:1 mixed-layer minerals in the soil which were calculated 
Table 4. Soil series classified according to the content of mica in surface soils (\% of inorganic soil material).

\begin{tabular}{cl}
\hline $\begin{array}{c}\text { Content } \\
\text { of mica }\end{array}$ & \multicolumn{2}{c}{ Soil series (Region) } \\
\hline$<5$ & $\begin{array}{l}\text { Sansai, Hangdong-Phimai (I), Roi Et (II), Klaeng (III, IVa), Lop Buri (III). } \\
\text { Guar. Tualang-Kundor (IVb) }\end{array}$ \\
$5-10$ & $\begin{array}{l}\text { Phimai (I). Ratchaburi (II), Saraburi, Ongkharak, Thanyaburi, Rangsit (III). } \\
\text { Samut Prakan (IVa), Kundor, Hutan(IVb) }\end{array}$ \\
$>10$ & Ayutthaya, Bang Khen, Bangkok (III) \\
\hline
\end{tabular}

Table 5. Soil series classified according to the contents of $2: 1$ mixed layer minerals" in surface soils ( $\%$ of inorganic soil material).

\begin{tabular}{|c|c|}
\hline $\begin{array}{c}\text { Contents of } \\
2: 1 \text { mixed } \\
\text { layer silicates }\end{array}$ & Soil series (Region) \\
\hline$<5$ & Sansai (I), Roi Et (II), Klaeng (III, IVa) \\
\hline $5-10$ & Hangdong-Phimai (I), Guar. Kundor. Hutan, Tualang-Kundor (IVb) \\
\hline $10-15$ & $\begin{array}{l}\text { Phimai (I), Ratchaburi (II), Ongkharak, Ayutthaya, Bang Khen, } \\
\text { Bangkok (III), Samut Prakan (IVa) }\end{array}$ \\
\hline$>15$ & Lop Buri, Saraburi, Thanyaburi, Rangsit (III) \\
\hline
\end{tabular}

1) Includes the contents of smectite and vermiculite as separate mineral species.

by combining the data given in Tables 2 and 3 . Their potential productivity is expected to increase from the soils at the top to those at the bottom in Tables 4 and 5 , if the soils have no significant limitations for rice production such as acidity, phosphate fixation, salinity, shallowness of Ap horizons etc. The estimated soil productivity increases from soils derived from old alluvium to those derived from semi-recent and recent alluvium and further to those derived from marine and brackish water deposits.

\section{ACKNOWLEDGEMENTS}

The authors wish to thank the grant given to this International Joint Research Project from the Japan Society for the Promotion of Science and the permission given to us by the National Research Council for the Regulations Governing the Promotion of Foreign Research in Thailand.

The authors also wish to thank Mr. Chob Kanareugsa, Dr. Jisuke Takahashi, Mrs. Jaovapa Hasathon, and Miss Jintana Somboondumrongkul in Rice Division, Mr. Wisit Cholitkul, late Dr. Manuwetaya Srisen, Mr. Bunharn Tangcham, and Mr. Samnao Phetchawee in Division of Agricultural Chemistry, Department of Agriculture (Thailand), Dr. Takanori Igarashi in Tropical Agriculture Research Centre (Japan), Dr. Niwat Hirunburana, Faculty of Agriculture, Chiang Mai University, Mr. Joseph Samy and Mr. Xavier Arulandoo in Malaysian Agricultural Research and Development Institute, and Dr. Hideaki Kai, Dr. Motoki Ikeda, Dr. Chitoshi Mizota, Dr. Sadao Kawaguchi, and Mr. Wittaya Masayna in Faculty of Agriculture, Kyushu University for their kind help in studying soils in the field and in collecting soil samples. 


\section{REFERENCES}

Barnhisel, R. I. 1977 Chlorites and hydroxy inter-layered vermiculite and smectite. In "Minerals in Soil Environments," ed. by J. B. Dixon and S. B. Weed, Soil Science Society of America, Madison, Wisconsin, pp. 331-356

Breemen, N. van 1976 Genesis and Solution Chemistry of Acid Sulfate Soils in Thailand. Centre for Agricultural Publishing and Documentation, Wageningen

Hattori, T. 1978 Soil minerals in paddy. In "Suiden Dojogaku," ed. by K. Kawaguchi, Kodansha. Tokyo, pp. 142-164 (in Japanese)

Hattori, T., H. Furukawa and K. Kawaguchi 1965 A few considerations on clay minerals in Thai paddy soils. Tonan Ajia Kenkyu, 3: 151-160 (in Japanese)

Huynh-tong-Tho and K. Egashira 1975 Some chemical, physical and mineralogical properties of acid sulfate soils from the Mekong Delta in Vietnam. J.Fac.Agr., Kyushu Univ., 20: 151-164

Inoue, K., M. Yoshida and K. Kaneko 1977 Chloritization of paddy soils caused by acidic irrigation-water. J. Sci. Soil Manure, Japan, 48: 193-200 (in Japanese)

Kawaguchi, K. and K. Kyuma 1969a Lowland Rice Soils in Thailand. Report on Research in Southeast Asia, Natural Science Series N-4. The Center for Southeast Asian Studies, Kyoto University, Kyoto (Japan)

Kawaguchi, K. and K. Kyuma 1969b Lowland Rice Soils in Malaya. Report on Research in Southeast Asia, Natural Science Series N-5. The Center for Southeast Asian Studies, Kyoto University, Kyoto (Japan)

Mitsuchi, M. 1974a Chloritization in lowland paddy soils. Soil Sci. Plant Nutr., 20: 107-116

Mitsuchi, M. 1974b Pedogenic characteristics of paddy soils and their significance in soil classification. Bull. Nat. Inst. Agric. Sci., B 25: 29-115

Motomura, S. 1973 The Report of the Joint-Research Work on "The Study on Advance in Rice Production by Soil Management" under the Cooperation Research Work Program between Thailand and Japan. Tropical Agriculture Research Center, Ministry of Agriculture and Forestry, Japan (Mimeograph material)

Vacharotayan, S., S. Rojanasoonthon and M. D. Dawson 1962 Characterization of selected Thai soils by means of X-ray diffraction, chemical and mechanical analysis. $J$. Nat. Res. Council, Thailand, 3: 207-223

Wada, K. 1966 Qualitative and quantitative determinations of clay minerals. J. Sci. Soil Manure, Japan, 37: 9-17 (in Japanese)

Wada, K. and H. Yamada 1968 Hydrazine intercalation-intersalation for differentiation of kaolin minerals from chlorites. Am. Mineralogist, 53 : 334-339 


\section{APPENDIX 1}

Soil profile description

\section{Site N 0. TL-1}

Location: Chiangmai University, Multiple Cropping Project, Experimental farm,

Village I, Suthep Muang, Chiang Mai

Reference : Mrs. Anpan Bhromsiri; Professor Niwat Hirunburana

Great soil group: Typic Ochraqualfs, Low Humic Gley soils

Soil series: Sansai

\begin{tabular}{|c|c|c|c|c|c|}
\hline Horizon & $\begin{array}{c}\text { Depth } \\
(\mathrm{cm})\end{array}$ & Color & $\begin{array}{l}\text { Mottles \& } \\
\text { concretions }\end{array}$ & Compactness ${ }^{2)}$ & Texture \\
\hline $\begin{array}{l}A p_{1} \\
A p_{2} \\
C_{1} \\
C_{2}\end{array}$ & $\begin{array}{l}0-13 \\
13-17 \\
17-35 \\
35+\end{array}$ & $\begin{array}{l}\text { 7. 5YR } 6 / 2 \\
7.5 \mathrm{YR} 7 / 2 \\
\mathrm{~N} 7-8 / 0 \\
\mathrm{~N} 7-8 / 0\end{array}$ & $\begin{array}{l}\mathrm{Fe}-\mathrm{m}+ \\
\mathrm{Fe}-\mathrm{m}+\mathrm{H} \\
\mathrm{Mn}-\mathrm{c}+\mathrm{Fe}-\mathrm{c} \pm \\
\mathrm{Mn}-\mathrm{c}+, \mathrm{Fe}-\mathrm{c}+\end{array}$ & $\begin{array}{l}10-13 \\
23-26 \\
25-28 \\
22-26\end{array}$ & $\begin{array}{l}\text { SL } \\
\text { SL } \\
\text { SL } \\
\text { n.d. }\end{array}$ \\
\hline
\end{tabular}

1) m. mottles; c, concretions. 2) Yamanaka's penetrometer reading.

Site N o. TL-2

Location: Mae Hear, Suthep, Meung. Chiang Mai

Reference : Farmer's field

Great soil group: Typic Ochraqualfs; Low Humic Gley soils

Soil series: Sansai

\begin{tabular}{|c|c|c|c|c|c|}
\hline Horizon & $\begin{array}{l}\text { Depth } \\
(\mathrm{cm})\end{array}$ & Color & $\begin{array}{c}\text { Mottles \& } \\
\text { concretions }\end{array}$ & Compactness & Texture \\
\hline $\begin{array}{l}\mathrm{Ap} \\
\mathrm{B}_{1}\end{array}$ & $\begin{array}{r}0-14 \\
14-21\end{array}$ & 10YR 6/2 10 YR $2 / 6$ & $\begin{array}{l}\mathrm{Fe}-\mathrm{m}+\underset{+}{H} \sim(0-0.5 \mathrm{~cm}) \\
\mathrm{Fe}-\mathrm{m}+\end{array}$ & $\begin{array}{l}16-22 \\
26-29\end{array}$ & $\begin{array}{l}\text { SL } \\
\text { SL }\end{array}$ \\
\hline $\begin{array}{l}\mathrm{B}_{2} \\
\mathrm{C}\end{array}$ & $\begin{array}{l}21-37 \\
37-50+\end{array}$ & $\begin{array}{l}\text { 10YR } 2 / 6 \\
10 \mathrm{YR} 5 / 1\end{array}$ & $\begin{array}{l}\mathrm{Fe}-\mathrm{m}+-\mathrm{Fe}-\mathrm{c} \#, \mathrm{Mn}-\mathrm{c} \\
\mathrm{Mn}-\mathrm{c}+, \mathrm{Fe}-\mathrm{c} \pm\end{array}$ & $\pm 23-27$ & SCL \\
\hline
\end{tabular}

Site No. TL-3

Location: San Pathong Rice Experiment Station, Chiang Mai

Reference : Miss Laddawan Loudhapasittiporen, O-O-O plot

Great soil group: Typic Tropaqualfs, Low Humic Gley soils

Soil series: Mae Khan (Hang Dong-Phimai; New classification)

\begin{tabular}{crllcl}
\hline Horizon & $\begin{array}{c}\text { Depth } \\
(\mathrm{cm})\end{array}$ & Color & $\begin{array}{c}\text { Mottles \& } \\
\text { concretions }\end{array}$ & Compactness & Texture \\
\hline $\mathrm{Ap}_{\mathbf{1}}$ & $0-10$ & $10 \mathrm{YR} 5 / 1$ & $\mathrm{Fe}-\mathrm{m}+\sim 11$ & $13-14$ & SCL \\
$\mathrm{Ap}_{\mathrm{G}}$ & $10-17$ & $5 \mathrm{G} 3 / 1$ & $\mathrm{Fe}-\mathrm{m}+$ & $17-23$ & $\mathrm{CL}$ \\
$\mathrm{B}$ & $17-30$ & $10 \mathrm{YR} 5 / 3$ & $\mathrm{Fe}-\mathrm{m}+$ & $23-24$ & $\mathrm{CL}$ \\
\hline
\end{tabular}

\section{Site N o. TL-4}

Location: Pa Ngae, Hankaeo. Hang Dong

Reference : Farmer's field

Great soil group : Typic Ochraqualfs ; Low Humic Gley soils

Soil series: Sansai 


\begin{tabular}{|c|c|c|c|c|c|}
\hline Horizon & $\begin{array}{l}\text { Depth } \\
(\mathrm{cm})\end{array}$ & Color & $\begin{array}{c}\text { Mottles \& } \\
\text { concretions }\end{array}$ & Compactness & Texture \\
\hline$A p$ & $0-7$ & $\begin{array}{l}7.5 \text { YR } 8 / 2 \\
7.5 \text { YR } 6 / 2 \\
\text { (mixture) }\end{array}$ & $\mathrm{Fe}-\mathrm{m}+$ & $28-29$ & $\mathrm{~L}$ \\
\hline $\begin{array}{l}\mathrm{C}_{1} \\
\mathrm{C}_{2}\end{array}$ & $\begin{array}{c}7-17 \\
17-30+\end{array}$ & $\begin{array}{r}\text { (mixture) } \\
7.5 Y R \quad 7 / 2 \\
7.5 Y R \quad 7 / 2 \\
6 / 2\end{array}$ & $\begin{array}{l}\mathrm{Mn}-\mathrm{c}+\mathrm{He}, \mathrm{Fe} \pm \\
\mathrm{Fe}-\mathrm{M}, \mathrm{Mn}-\mathrm{c}+\end{array}$ & $\begin{array}{l}31-34 \\
30-32\end{array}$ & $\begin{array}{l}\mathrm{L} \\
\mathrm{L}\end{array}$ \\
\hline
\end{tabular}

Site No. TL-5

Location: Rim Ping, Rim Ping, Lamphun

Reference : Farmer's field

Great soil group : Vertic Tropaquepts ; Hydromorphic Alluvial soils

Soil series: Phimai

\begin{tabular}{cccccc}
\hline Horizon & $\begin{array}{c}\text { Depth } \\
(\mathrm{cm})\end{array}$ & Color & $\begin{array}{c}\text { Mottles \& } \\
\text { concretions }\end{array}$ & Compactness & Texture \\
\cline { 1 - 3 } $\mathrm{Ap}_{\mathrm{G}}$ & $\mathrm{O}-18$ & $7.5 \mathrm{GY} \mathrm{4/1}$ & Fe-m & $3-7$ & $\mathrm{LiC}$ \\
$\mathrm{B}_{\mathbf{1 g}}$ & $18-33$ & $7.5 \mathrm{GY} / 1$ & $\mathrm{Fe}-\mathrm{m}$ H & $17-18$ & $\mathrm{HC}$ \\
$\mathrm{B}_{\mathbf{2 g}}$ & $33-50+$ & $7.5 \mathrm{GY} 5 / 1$ & Fe-m H & $13-16$ & $\mathrm{HC}$
\end{tabular}

Site No. TL-6

Location: Phan Rice Experiment Station, Phan, Phan, Chiang Rai

Reference : $\mathrm{O}-\mathrm{O}-\mathrm{O}$ plot (replication 1)

Great soil group : Vertic Tropaquepts; Hydromorphic Alluvial soils

Soil series: Hang Dong/Phimai series

\begin{tabular}{|c|c|c|c|c|c|}
\hline Horizon & $\begin{array}{l}\text { Depth } \\
(\mathrm{cm})\end{array}$ & Color & $\begin{array}{c}\text { Mottles \& } \\
\text { concretions }\end{array}$ & Compactness & Texture \\
\hline $\begin{array}{l}\mathrm{Ap}_{\mathrm{g}} \\
\mathrm{B}_{\mathrm{g}}\end{array}$ & $\begin{array}{c}\text { o- } 12 \\
12-30+\end{array}$ & $\begin{array}{l}7.5 Y R \quad 5 / 6 \\
7.5 Y R \quad 4 / 3\end{array}$ & $\overline{\mathrm{Fe}}-\mathrm{m}+$ & $\begin{array}{l}10-15 \\
18-20\end{array}$ & $\begin{array}{l}\mathrm{HC} \\
\mathrm{HC}\end{array}$ \\
\hline
\end{tabular}

Site No. TL-7

Location: Chum Phae Rice Experiment Station, Chum Phae. Khon Kaen

Reference : $\mathrm{O}-\mathrm{O}-\mathrm{O}$ plot (replication 1)

Great soil group: Aeric Tropaquepts; Hydromorphic Alluvial soils

Soil series: Ratcha Buri

\begin{tabular}{|c|c|c|c|c|c|}
\hline Horizon & $\begin{array}{l}\text { Depth } \\
(\mathrm{cm})\end{array}$ & Color & $\begin{array}{c}\text { Mottles \& } \\
\text { concretions }\end{array}$ & Compactness & Texture \\
\hline $\begin{array}{l}\mathrm{Ap}_{1} \\
\mathrm{~B}_{1 \mathrm{~g}}\end{array}$ & $\begin{array}{c}0-12 \\
12-30+\end{array}$ & $\begin{array}{l}5 \mathrm{YR} 5 / 3 \\
5 \mathrm{YR} 5 / 2\end{array}$ & $\begin{array}{l}\mathrm{Fe}-\mathrm{m}+, \mathrm{Mn}-\mathrm{c} \pm \\
\mathrm{Fe}-\mathrm{m}+, \mathrm{Mn}-\mathrm{c} \pm\end{array}$ & $\begin{array}{l}24-28 \\
20-23\end{array}$ & $\begin{array}{l}\mathrm{LiC} \\
\mathrm{LiC}\end{array}$ \\
\hline
\end{tabular}

Site No. TL-8

Location: Wong Kohlek, Lam Phan, Muang, Kalasin

Reference : UN-FAO Demonstration Farm

Great soil group : Aeric Paleaquults ; Low Humic Gley soils

Soil series: Roi Et, loamy variant 


\begin{tabular}{cccccc}
\hline Horizon & $\begin{array}{c}\text { Depth } \\
(\mathrm{cm}>\end{array}$ & Color & $\begin{array}{c}\text { Mottles \& } \\
\text { concretions }\end{array}$ & Compactness & Texture \\
\hline $\mathrm{Ap}_{\mathbf{1}}$ & $\mathbf{0 - 1 3}$ & $7.5 \mathrm{YR} \mathrm{8/3}$ & $\mathrm{Fe}-\mathrm{m}+$ & $28-33$ & SL \\
$\mathrm{B}_{\mathbf{1}}$ & $13-30$ & $7.5 \mathrm{YR} 6 / 3$ & $\mathrm{Fe}-\mathrm{m} \mathrm{Ht}, \mathrm{Mn}-\mathrm{c}$ tt & $33-36$ & SCL \\
\hline
\end{tabular}

Site No. TL-9

Location: Sida, Nongson. Chiang Yun. Maha Sarakham

Reference : Farmer's field

Great soil group: Typic Natraqualfs ; Solonchak ?

Soil series: Roi Et, salt affected

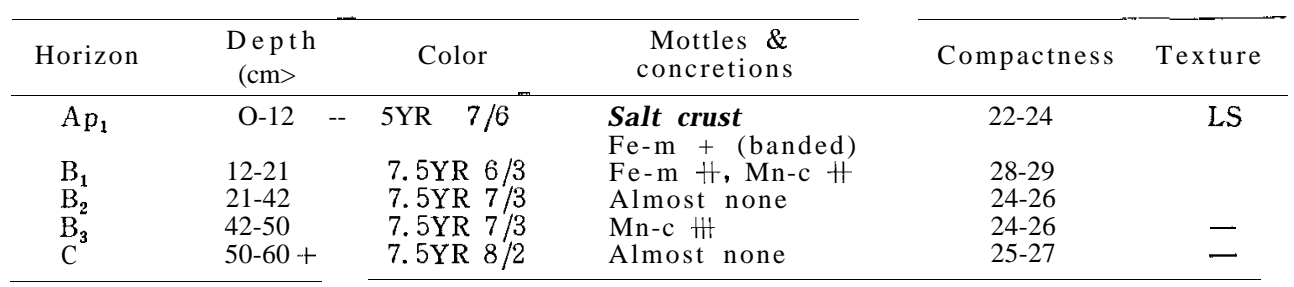

\section{Site No. TL-10}

Location :Rangsit Rice Experiment Station, Rangsit, Thanyaburi, Pathum Thani

Reference: near to O-O-O plot

Great soil group: Sulfic Tropaquepts ; Alluvial soils

Soil series : Thanyaburi

\begin{tabular}{|c|c|c|c|c|c|}
\hline Horizon & $\begin{array}{l}\text { Depth } \\
(\mathrm{cm}>\end{array}$ & Color & $\begin{array}{l}\text { Mottle \& } \\
\text { concretions }\end{array}$ & Compactness & Texture \\
\hline AP & $0-25$ & 7. 5YR 2/1 & $\mathrm{Fe}-\mathrm{m}+$ & $11-14$ & $\mathrm{HC}$ \\
\hline $\begin{array}{l}\text { AP } \\
B_{18}\end{array}$ & 25-35 & $\begin{array}{l}7.5 \text { YR 2. } 2 / 1 \\
7.5 \text { YR } 6 / 3\end{array}$ & $\mathrm{Fe}-\mathrm{m}+$ & $19-20$ & $\mathrm{HC}$ \\
\hline $\mathrm{B}_{12 \mathrm{~g}}$ & 35-62 & $\begin{array}{l}\text { (mixture) } \\
7.5 \text { YR } 6 / 3 \\
10-7.5 R 4 / 6-8 \\
7.5 Y R 7 / 8\end{array}$ & Fe-m H & $16-19$ & $\mathrm{HC}$ \\
\hline $\mathrm{B}_{228}$ & 62-82 & $\begin{array}{l}7.5 \text { YR } 6 / 3 \\
10-7.5 R 4 / 6-8 \\
7.5 \text { YR } 7 / 8 \\
\text { (mixture) }\end{array}$ & $\mathrm{Fe}-\mathrm{m}$ HH & $14-15$ & $\mathrm{HC}$ \\
\hline
\end{tabular}

Site No. TL-11

Location : Ongkharak Land Development Experiment Station, Ongkharak, Nakhon Nayok

Reference : Left fallow

Great soil group: Sulfic Tropaquepts; Alluvial soils

Soil series: Rangsit, very acid phase

\begin{tabular}{|c|c|c|c|c|c|}
\hline Horizon & $\begin{array}{l}\text { Depth } \\
(\mathrm{cm})\end{array}$ & Color & $\begin{array}{c}\text { Mottles \& } \\
\text { concretions }\end{array}$ & Compactness & Texture \\
\hline $\begin{array}{l}{ }_{1} A_{1} \\
\mathrm{~B}_{2} \mathrm{~B}_{1}\end{array}$ & $\begin{array}{c}0-15 \\
27-8015-27\end{array}$ & $\begin{array}{l}\text { 7.5YR } 3 / 1 \\
7.5 Y R 7,5 Y R \\
6 / 9778\end{array}$ & $\begin{array}{l}\mathrm{Fe}-\mathrm{m} \quad \pm \\
\mathrm{Fe}-\mathrm{m}\end{array}$ & $\begin{array}{l}19-20-15 \\
\mathbf{1 3 - 1 6}\end{array}$ & $\begin{array}{l}\mathrm{HC} \\
\mathrm{HC} \\
\mathrm{HC}\end{array}$ \\
\hline
\end{tabular}


Site No. TL-12

Location: Suphan Buri Rice Experiment Station, Rown Yai, Muang, Suphan Buri Reference : O-O-O plot

Great soil group: Aeric Tropaquepts; Alluvial soils

Soil series : Saraburi

\begin{tabular}{|c|c|c|c|c|c|}
\hline Horizon & $\begin{array}{c}\text { Depth } \\
(\mathrm{cm})\end{array}$ & Color & $\begin{array}{l}\text { Mottles \& } \\
\text { concretions }\end{array}$ & Compactness & Texture \\
\hline $\begin{array}{l}\mathrm{Ap}_{18} \\
\mathrm{Ap}_{28}\end{array}$ & $\begin{array}{l}0-7 \\
7-15\end{array}$ & $\begin{array}{l}7.5 Y R \quad 5 / 6 \\
10 Y R ~\end{array}$ & $\begin{array}{l}\mathrm{He}-\mathrm{m}^{-}+ \\
\mathrm{Fe}-\mathrm{c} \pm\end{array}$ & $8-9$ & $\mathrm{LiC}$ \\
\hline $\mathrm{B}_{1}$ & $15-24$ & $10 \mathrm{YR} 3 / 3$ & $\mathrm{Fe}-\mathrm{c} \pm, \mathrm{Fe}-\mathrm{m} \pm$ & $19-22$ & $\mathrm{LiC}$ \\
\hline $\mathrm{B}_{2}^{2}$ & $24-50+$ & $7.5 \mathrm{YR} 7 / 8$ & $\mathrm{Fe}-\mathrm{m}+$ & $19-22$ & $\mathrm{HC}$ \\
\hline
\end{tabular}

Site No. TL-13

Location : Khlong Luang Rice Experiment Station, Khlong Nung, Khlong Luang, Pathum Thani

Reference: Long term application of ammonium sulfate. Exp. plot 1.

Great soil group: Sulfic Tropaquepts; Alluvial soils

Soil series : Thanyaburi

\begin{tabular}{|c|c|c|c|c|c|}
\hline Horizon & $\begin{array}{l}\text { Depth } \\
(\mathrm{cm})\end{array}$ & Color & $\begin{array}{c}\text { Mottles \& } \\
\text { concretions }\end{array}$ & Compactness & Texture \\
\hline $\begin{array}{l}\mathrm{An} \\
\mathrm{Ap}_{2} \\
\mathrm{~B}_{1} \\
\mathrm{~B}_{2}\end{array}$ & $\begin{array}{r}0-17 \\
17-25 \\
27-35 \\
35-50\end{array}$ & $\begin{array}{l}\text { 7.5YR } 4 / 1 \\
7.5 Y R ~ 3 / 1 \\
7.5 Y R ~ 5 / 1 \\
7.5 Y R ~ 7 / 2 \\
7.5 Y R 5 / 1 \\
\text { (mixture) }\end{array}$ & $\begin{array}{l}\mathrm{Fe}-\mathrm{m} \pm \\
\mathrm{Fe}-\mathrm{m}+ \\
\mathrm{Fe}-\mathrm{m} \text { it } \\
\mathrm{Fe}-\mathrm{m} \text { it, Mn-c }+\end{array}$ & $\begin{array}{l}24-27 \\
19-21 \\
22-23 \\
18-20\end{array}$ & $\begin{array}{l}\mathrm{SiC} \\
\mathrm{SiC} \\
\mathrm{SiC} \\
\mathrm{HC}\end{array}$ \\
\hline
\end{tabular}

\section{Site No. TL-25}

Location : Nongteenok, Banpho. Chachoengsao

Reference : Farmer's field

Great soil group: Oxic Plinthaquults; Low Humic Gley soils

Soil series: Klaeng

\begin{tabular}{|c|c|c|c|c|c|}
\hline Horizon & $\begin{array}{c}\text { Depth } \\
(\mathrm{cm})\end{array}$ & Color & $\begin{array}{c}\text { Mottles \& } \\
\text { concretions }\end{array}$ & Compactness & Texture \\
\hline $\begin{array}{l}A p_{1} \\
C_{1} \\
C_{2}\end{array}$ & $\begin{array}{r}0-16 \\
16-32 \\
32-55\end{array}$ & $\begin{array}{l}5 \mathrm{YR} 3 / 1 \\
10 \mathrm{YR} 3 / 34 \\
2.5 \mathrm{YR} 4 / \\
10 \mathrm{YR} 6 / 1\end{array}$ & $\begin{array}{l}\text { Almost none } \\
\text { Fe-m + } \\
\text { Fe-m H, Mn ? } \\
\text { gypsum-c }\end{array}$ & $\begin{array}{l}22 \\
23 \\
18\end{array}$ & $\begin{array}{l}\text { SL } \\
\text { SC } \\
\mathrm{LiC}\end{array}$ \\
\hline $\mathrm{C}_{3 \mathrm{~g}}$ & $55+$ & $5 Y R 7.5 / 1$ & $\mathrm{Fe}-\mathrm{m}+$ & 18 & SL \\
\hline
\end{tabular}




\section{APPENDIX 2}

Soil sample description

\begin{tabular}{|c|c|c|c|}
\hline Site No. & Location & Soil series & Management \\
\hline TL-2 1 & $\begin{array}{l}\text { Raheng. Ra Lungeo, } \\
\text { Pathum Thani }\end{array}$ & Ayutthaya & Farmer's field \\
\hline TL-22 & $\begin{array}{l}\text { Bang-Pa-Sri, Banglen, } \\
\text { Nakhon Pathom }\end{array}$ & Bang Khen & " \\
\hline TL-23 & $\begin{array}{l}\text { Lampakchee, Nongshok, } \\
\text { Bangkok }\end{array}$ & Bangkok & " \\
\hline TL-24 & $\begin{array}{l}\text { Namdang. Muang, } \\
\text { Chachoengsao }\end{array}$ & " & " \\
\hline TL-27 & $\begin{array}{l}\text { Kao-Sam-Yod, Muang. } \\
\text { Lop Buri }\end{array}$ & Lop Buri & " \\
\hline TL-29 & $\begin{array}{l}\text { Sisakrabu. Ongkharak } \\
\text { Nakhon Nayok }\end{array}$ & Ongkharak & " \\
\hline TL-30 & $\begin{array}{l}\text { Nakhon Si Thamrat } \\
\text { Rice Experiment Station, } \\
\text { Nakhon Si Thamrat }\end{array}$ & Samut Prakan & Experiment plot \\
\hline TL-31 & $\begin{array}{l}\text { Kuan Gut Rice } \\
\text { Experiment Station, } \\
\text { Phatthalung }\end{array}$ & Klaeng & " \\
\hline TL-32 & $\begin{array}{l}\text { Pattani Rice Experiment } \\
\text { Station }\end{array}$ & " & " \\
\hline ML-11 & $\begin{array}{l}\text { Rice Research Station, } \\
\text { MARDI, Bumbong Lima, } \\
\text { Kepala Batas, Penang }\end{array}$ & $\begin{array}{l}\text { Tualang } \\
\text { Kundor }\end{array}$ & $\begin{array}{l}\text { Long term NPK } \\
\text { test plots }\end{array}$ \\
\hline ML-12 & $" 1$ & " & $" 1$ \\
\hline ML-13 & Alor Cik Kendu & Hutan & $\begin{array}{l}\text { Farmer's field: } N \\
\text { application growth } \\
\text { stage trial }\end{array}$ \\
\hline ML-14 & Pendang. Kedah & Kundor & Farmer's field \\
\hline ML-15 & Guar Chempedak, Kedah & Guar & " \\
\hline
\end{tabular}

